\title{
The Implementation of Mini Volleyball in Physical Education to Increase Students' Creative Thinking Ability
}

\author{
Dupri", Oki Candra, Novia Nazirun \\ Department of Physical Education, Health and Recreation FKIP Islamic University of Riau, Jl. Kaharuddin Nst No.113, Simpang Tiga, \\ Kec. Bukit Raya, Pekanbaru, Riau, Indonesia
}

Received April 23, 2021; Revised June 16, 2021; Accepted July 21, 2021

\section{Cite This Paper in the following Citation Styles}

(a): [1] Dupri, Oki Candra, Novia Nazirun, "The Implementation of Mini Volleyball in Physical Education to Increase Students' Creative Thinking Ability," International Journal of Human Movement and Sports Sciences, Vol. 9, No. 4A, pp. 89 - 93, 2021. DOI: 10.13189/saj.2021.091315.

(b): Dupri, Oki Candra, Novia Nazirun (2021). The Implementation of Mini Volleyball in Physical Education to Increase Students' Creative Thinking Ability. International Journal of Human Movement and Sports Sciences, 9(4A), 89 93. DOI: 10.13189/saj.2021.091315.

Copyright $\bigcirc 2021$ by authors, all rights reserved. Authors agree that this article remains permanently open access under the terms of the Creative Commons Attribution License 4.0 International License

\begin{abstract}
The challenges of the current industrial revolution era 4.0 have an impact on the skills that must be possessed by the younger generation, one of which is the ability to think creatively to face fast technological developments. Therefore, the research objective was to observe the effect of volleyball on students' creative thinking skills. The method used was an experimental design with one group of pre-test post-test each. Meanwhile, the research location was a high school, and a sample size of thirty-five students from the tenth grade was selected by cluster random sampling. This research was conducted for two months, with meetings held weekly, resulting in a total of eight sessions. The ability to think creatively was evaluated with the Torrance Test of Creative Thinking (TTCT), while t-tests were employed for the data analysis. Subsequently, the study results indicated an increase in creative abilities at the application of volleyball during physical education learning. With this research outcome, it is necessary to perform other development studies, which involve utilizing a control group and more interesting strategies. Consequently, mini volleyball modification is suitable to be applied in physical education learning at schools because it provides a sense of comfort, joy, and activity in the game.
\end{abstract}

Keywords Mini Volleyball, Creative Thinking

\section{Introduction}

There are three main aspects of 21st Century Life Skills, including: Learning and Innovation Skills, Life and career skills, and Digital Literacy (Information, Media and Technology Skills) [1]. Based on the competence of the 21 st century, the quality of education must be able to produce graduates who can compete globally. To answer the challenges of this era of education must be able to produce graduates who are competitive, innovative, creative, collaborative and characterized. In addition, creative thinking skills are very important in today's modern society, especially in facing the 4.0 industrial revolution because it can make people become more flexible, open, and adaptable to various situations and problems in life [2]. Critical thinking, creative thinking, communication and collaboration are four indicators that indicate Learning and Innovation skills that must be possessed [3]. Creative thinking is important because the initial stage is for people to be able to do critical thinking, which will enable someone to come up with new ideas, ideas and breakthroughs. So by having the ability to think creatively, we hope that it will not be difficult to face challenges and be creative in the era of society 5.0 in the future.

Physical Education (PE) is one of the lessons in schools that uses physical activities as a tool to achieve educational goals. The hope of implementing Physical 
Education in schools is to contribute to the development of the potential of students through the skills students have, so that these skills can contribute to their future prosperity. The learning experience in physical education that is achieved by school students is a process of investing the value of education through physical activity and sports that are applied. From the teacher, in the end good habits can be applied by students in everyday life in society [4]. From early childhood to adolescence, children's cognitive functions are very rapidly changing, social and intellectual activities require many cognitive functions [5]. During social interactions, assumptions about other people's thoughts guide children's actions and frame their interpretations of other people's actions. PE not only contributes to basic motor skills and fitness, but also develops humans from various aspects, such as cognitive and affective aspects [6].

Schools in providing education have a role in developing children's creative abilities. A teacher will become a facilitator in achieving children's creative thinking skills. The reality in the field of physical education learning in schools can be seen today that students in creative thinking include students who are still less active in learning, teachers dominate in learning so students are more likely to be passive, teachers tend to demonstrate learning directly to students. So that the motivation for students in developing students' creative thinking will not be realized. The eight must have in developing creative thinking can be divided into two groups, namely four on cognitive elements and four on affective elements, consisting of flexibility, fluent thinking, elaboration, curiosity, originality, elaboration, complexity, curiosity, imagination, taking risks [7]. Another thing that is able to support creative thinking like what is said [7] is someone who has implicative thinking, likes challenging thoughts, and is also ideal.

Presenting interesting and developing learning in any way needs to prepare interactive and fun learning. One way is by modification. Modification is analysis as well as developing subject matter by guiding it in the form of learning activities that have the potential to facilitate students' learning [8]. In addition, learning must also adapt to the characteristics of the child which is also called Developmentally Appropriate Practice (DAP). This means that the teaching assignment given must pay attention to changes in children's abilities and can help encourage these changes [9]. Evidence shows that the
DAP approach has a positive impact on children's learning and development [10] thus, children feel their learning is more meaningful in schools that implement DAP approach [11] and show better psychological well-being results in terms of self-competence [12] and self-efficacy and social skills [13].

With a simple modification that offers mini volleyball, teachers can easily provide their children with a volleyball experience that is fun and rewarding. One of the main goals of mini volleyball coaching is to encourage child development through sports activities. In addition, the purpose of playing mini volleyball is so that children know and like it, so that children can play volleyball, so that they become supporters (spectators, organizers, referees), become athletes for potential (nurseries), provide a physical basis, techniques, and strong tactics for achievement [14]. Mini volleyball focuses more on learning not on the direction of achievement. The joy in playing volleyball is what the coach must prioritize, because with children getting joy in playing this sport, many children will be involved in the game and with the many children involved, the volleyball sport will be realized. Volleyball game in physical education is a medium for teaching students about character values, such as cooperation, confidence, responsibility, courage, and being a sports person [15].

\section{Methods}

The research method chosen from this study was a quasi-experiment with a pre-test and post-test control group design. This research will be conducted at public senior high school in Indonesia. The population in this study were tenth graders of the senior high school, which amounted to 321 students. The sampling chosen in this study was cluster random sampling, so the sample in this study amounted to 70 people consisting of class X IPA (science class) I (experimental) and X IPA III (control). The instrument used to measure students' creative thinking skills used the Test of Creative Thinking (TTCT) (Kim, 2011). This instrument is in the form of a creative thinking questionnaire consisting of 5 indicators, namely: 1) Fluent Thinking, 2) Elaboration, 3) Flexible Thinking, 4) Conclusion, 5) Abstract Title. The grid for this questionnaire is as follows: 
Table 1. Grid Creative Thinking Questionnaire

\begin{tabular}{|c|c|c|}
\hline Variables Research & Indicator & Description \\
\hline \multirow{10}{*}{$\begin{array}{l}\text { Skills thinking creative of } \\
\text { students }\end{array}$} & \multirow{3}{*}{ Ability to think fluently } & a) Come up with lots of answers, ideas, problem solving and questions \\
\hline & & b) Provide many ways or suggestions for doing various things \\
\hline & & c) Always think of more than one answer \\
\hline & \multirow{3}{*}{ Ability to think flexibly } & a) Generate various ideas, answers and questions \\
\hline & & b) Can see a problem with different directions of thought \\
\hline & & c) Be able to change the way of approach or thought \\
\hline & \multirow{2}{*}{ Ability to think original } & a) Able to produce unique and new expressions \\
\hline & & b) Be able to make unusual combinations of parts or elements. \\
\hline & \multirow{2}{*}{ Ability to think in detail } & a) Develop, add, enrich an idea \\
\hline & & b) Able to detail the details of an object so that it becomes interesting \\
\hline
\end{tabular}

Before going to the field, this research instrument will test the validity and reliability, namely based on the results of these calculations as many as 32 test items were declared valid and their reliability with a Cronbach's Alpha value of 0.845 . Before conducting a research analysis of the data obtained, the normality and homogeneity test will first be carried out. The t test was used to perform the analysis of this study with the SPSS 22 stone.

\section{Results}

Before obtaining data for analysis, this study provided 8 meetings outside the pre-test and post-test. The analysis carried out in this study used the t-test of the pre-test and post-test results in both the experimental group and the control group. Based on the results of the analysis carried out, it was found that the results of this study are as shown in the table below:

Table 2. Paired Samples Test for Creative Thinking

\begin{tabular}{ccccc}
\hline & Mean & T & Df & $\begin{array}{c}\text { Sig. }(2 \\
\text { tailed })\end{array}$ \\
\hline $\begin{array}{c}\text { Pretest- Posttest group } \\
\text { Mini volleyball } \\
\begin{array}{c}\text { Pretest-Posttest group } \\
\text { Control }\end{array}\end{array}$ & 88 & 8,956 & 35 & .000 \\
\hline
\end{tabular}

From the results of the Paired Samples Test which can be seen in Table 2 above, the sig value is $0.000<\alpha=0.05$. These results prove that physical education learning using mini volleyball games has a significant effect on improving students' creative thinking. A different thing happened to physical education learning which was carried out without the mini volleyball game, showing that it was not proven to significantly improve students' creative thinking skills.

Table 3. Independent Samples Test

\begin{tabular}{ccccc}
\hline F & Sig & T & Df & Sig. (2-tailed) \\
\hline 8.175 & .000 & 5.134 & 69 & .000 \\
\hline
\end{tabular}

The results of the Independent Samples Test in Table 3 above show that the gain of the discovery learning model and the conventional model obtained a sig value of 0.000 $<\alpha=0.05$, this means that there are differences in students' creative thinking skills through physical education learning between the mini volleyball group and the control group. Creative thinking skills that emerge through mini volleyball games can create more active learning from the students themselves. When seen in the table. 1 mean value of the mini volleyball group was 88 , while in control learning it was 73 , this means that the creative thinking ability of students in the mini volleyball group was better than the control group.

Table 4. Students' creative thinking ability test

\begin{tabular}{ccccc}
\hline \multirow{2}{*}{ Components of } & \multicolumn{2}{c}{ mini volleyball } & \multicolumn{2}{c}{ Control } \\
\cline { 2 - 5 } & Pre-test & Post-test & Pre-test & Post-test \\
\hline Less creative & 10 & 3 & 6 & 2 \\
Quite Creative & 15 & 7 & 20 & 21 \\
Creative & 10 & 20 & 9 & 11 \\
Very Creative & 0 & 5 & 0 & 1 \\
N & 35 & 35 & 35 & 35 \\
\hline
\end{tabular}

From the table 4, it can be seen that the creative thinking skills of students with physical education learning with mini volleyball games have increased, which at first were classified as creative by only 10 people and after treatment it became 20 people and those who were sufficient and less creative had decreased. The control class gained an increase in the number at the creative level, only 2 people and more at the creative level, namely 21 people. As shown in the diagram below:

\section{Discussion}

Mini volleyball modification is suitable to be applied to physical education learning in schools, because it provides a sense of comfort, joy, and activity in games. The learning process that gives students time to find interesting forms of play in learning provides opportunities for students to think creatively, which is the essence of learning carried out in this study. Not only that, the creative form of students also develops in the form of skills that appear when playing in the field to be able to get numbers, as also expressed by [16] that through games 
in physical education learning will develop social interaction skills, collaboration skills and creativity developing through a game that is presented, because by playing new ideas will emerge from the results of thoughts for solving problems in a game and creating new things from a game.

Research evidence shows that movement and creativity are closely related. [17] Intervention programs have been implemented to promote children's creative potential through movement, an inquiry into European school curricula which promote creativity establishes Physical Education among the most popular subjects in schools, in Greece, for at least the last decade, motor creativity children have been promoted through the physical education curriculum, especially in first grade. However, research that supports increased creativity in Physical Education is very limited, because it focuses more on evaluating children's motor responses. Around the world, although it is necessary to investigate, through implicit theory, teachers' perceptions of creativity and its promotion in various disciplines, it seems that this kind of research is still in its infancy.

When analyzed from a motor point of view [18], it is concluded that motor perceptual ability affects intellectual, social and emotional development. Perceptual motor encourages a person to explore knowledge from his environment and enables them to control their body against external objects and has a good quality of motion. A creative play environment is the basic philosophy of a form of learning that can develop creativity in early childhood [19]. Various studies have shown that imagination games (symbolic play) can develop various abilities, including creativity, memory development, cooperation, vocabulary acceptance, friendship, and self-control. [18] states that creativity in children has developed since the age of 4 years, it can be seen in the lower brain structure which has reached $80 \%$. In this phase, motor functions begin to develop and interact with the environment. Meanwhile the emotional-cognitive system develops through playing, imitating and reading stories. Meanwhile, a higher intelligence will develop if the child is properly cared for with attention to their emotional health.

Making students confident in expressing opinions, assisted by the support or motivation of the teacher, can develop student creative thinking skills because giving positive feedback has a positive effect on children self-development [20]. With self-esteem in students, it will be easier for students to think creatively to develop properly.

The impact of this research is not only able to develop creative abilities in students, but also has an impact on teachers to be able to prepare creative learning for creative learning in physical education. As stated by [21] for creative learning, creative teachers are needed in presenting learning, it can be seen through the personality of a teacher. Besides that, schools also have an important role in supporting the success of creative learning, creative teachers in teaching and for students to be creative.

The ability to solve problems has an important role in the creative performance of teachers, and physical education is very different from other education [22]. It focuses on physical activity and has characteristics of diversity, spatialization, and humanization; In addition to developing motor skills and mental intelligence, physical education teaching often uses collective activities to promote positive personality and social development for adolescents. Therefore, in an environment of physical education teachers, if school support can further assist the teacher resilience, it may be more conducive to encouraging creative performance; conversely, if environmental factors undermine the their resilience, their creative teaching performance may suffer. Therefore, school environmental factors can directly influence their creativity, or can indirectly influence individual creative performance by stimulating or inhibiting individual creativity resilience. That is, resilience may have an intermediate effect between school support and creative teaching performance. This is another point of view in developing students' creative thinking skills in this study.

The game of volleyball has difficulties in playing it such as arranging various attacks so that it is not read by the opponent, defending both from an opponent's attack and when receiving service and looking for an empty area when attacking with a smash or serving [23], this will develop students' creativity in overcome difficulties in this game.

Furthermore, there is a need for research on approaches that are able to develop creative thinking skills in students because approach is very important for school children individual development [24]. Then we have to pay attention to use the right approach in providing physical education learning

\section{Conclusion}

The results of this study found that learning with mini volleyball was indeed able to improve creative thinking skills through physical education learning in schools with sig. 0,000 . The keys to increasing creativity are through creative teaching, teaching for creativity, and creative learning. Even so, researchers invite other researchers to continue to find patterns of good learning models to develop the character of students well. This learning model must be applied in various fields of education. Research on the same topic must be carried out in the future, with a variability in the level of education of different subjects or educational institution settings. There is no difference in terms of gender and cognitive abilities of students in seeing students' creative thinking abilities is 
something that needs to be discussed further.

\section{Acknowledgments}

Special thanks to Dr. Oki Candra, M.Pd for their assistance during this research as well as to Novia Nazirun, M.Kes, and Novri Gazali, M.Pd who have made this paper finalized, and to the ministry of Education and Culture who has funded this research on the beginner research scheme.

\section{REFERENCES}

[1] Triling B, Fadel C. 21st century skills: learning for life in our times. San Fransisco: Joey-Bass. 2009.

[2] Hanifah W, Subiyantoro S. Creative Thinking Skills in Science Lessons in Elementary Schools. In3rd International Conference on Learning Innovation and Quality Education (ICLIQE 2019) 2020 Feb 6 (pp. 870-875). Atlantis Press.

[3] Dupri, Nazirun N, Risma N. Penerapan Model Problem Based Learning Untuk Meningkatkan Keterampilan Berpikir Kritis Pada Pendidikan Jasmani. Journal Sport Area. 2019

[4] Suherman A. Revitalisasi pengajaran dalam pendidikan jasmani. Bandung: CV. Bintang Warli Artika. 2009.

[5] Stephani MR, Solihin AO, Kharisman VA. The Implementation of VOBAS Game Modification to Critical Thinking Ability in Senior High School Students. InIOP Conference Series: Materials Science and Engineering 2017 Mar 1 (Vol. 180, No. 1, p. 012169). IOP Publishing.

[6] McBride RE, Gabbard CC, Miller G. Teaching critical thinking skills in the psychomotor domain. The Clearing House. 1990 Jan 1;63(5):197-201.

[7] Bacanl1 H, Dombaycı MA, Demir M, Tarhan S. Quadruple thinking: Creative thinking. Procedia-Social and Behavioral Sciences. 2011 Jan 1;12:536-44.

[8] Kurniawan D. Pengaruh Modifikasi Permainan Bolavoli terhadap Kerjasama Siswa pada Pembelajaran Pendidikan Jasmani, Olahraga dan Kesehatan (Studi pada siswa kelas X Boga 1 SMKN 3 Probolinggo). Jurnal Pendidikan Olahraga dan Kesehatan. 2014 Dec 13;3(1).

[9] Wong YH, Li-fang Z. Personality types of Hong Kong kindergarten teachers: Implications for teacher education. Australian Journal of Teacher Education. 2013;38(2):6.

[10] Paul WY. Teaching Beliefs on Developmentally Appropriate Practice Among Chinese Preschool Teachers: The Role of Personality. Frontiers in Psychology. 2019; 10:2822.
[11] Lee PN, Lin SH. Music teaching for young children at a developmentally appropriate practice classroom in Taiwan. Music Education Research. 2013 Mar 1;15(1):107-22.

[12] Jambunathan S. Developmentally appropriate practices and children's perception of self-competence in Head Start classrooms. Education 3-13. 2012 Jun 1;40(3):271-9.

[13] Marcon RA. Moving up the Grades: Relationship between Preschool Model and Later School Success. Early Childhood Research \& Practice. 2002;4(1):n1.

[14] Sujarwo.Kemampuan Dasar Dalam Bola Voli Mini. Journal of Chemical Information and Modeling. 2018

[15] Mawarti S. Permainan bolavoli mini untuk anak sekolah dasar. Jurnal Pendidikan Jasmani Indonesia. 2009;6(2).

[16] Wibowo YA. Bermain dan Kreativitas dalam Pembelajaran Pendidikan Jasmani. Jurnal Pendidikan Jasmani Indonesia. 2010;7(2):15-20.

[17] Konstantinidou E, Gregoriadis A, Grammatikopoulos V, Michalopoulou M. Primary physical education perspective on creativity: the nature of creativity and creativity fostering classroom environment. Early Child Development and Care. 2014 May 4;184(5):766-82.

[18] Rachman HA. Membangun Kembali Jembatanantara Kreativitas Dan Pendidikan Jasmani. Jurnal Pendidikan Jasmani Indonesia. 2006;5(1).

[19] Priyanto A. pengembangan kreativitas pada anak usia dini melalui Aktivitas bermain. Jurnal Ilmiah Guru Caraka Olah Pikir Edukatif. 2014(2).

[20] Dupri D, Nazirun N. The Effort to Develop Junior High School Students Self-Esteem Through Giving Positive Feedbacks. In4th International Conference on Sport Science, Health, and Physical Education (ICSSHPE 2019) 2020 Feb 19 (pp. 71-74). Atlantis Press.

[21] Deng Q, Zheng B, Chen J. The Relationship Between Personality Traits, Resilience, School Support, and Creative Teaching in Higher School Physical Education Teachers. Frontiers in Psychology. 2020 Sep 24;11:2397.

[22] Mancini AD, Bonanno GA. Predictors and parameters of resilience to loss: Toward an individual differences model. Journal of personality. $2009 \mathrm{Dec} ; 77(6): 1805-32$.

[23] Chanh Thuc Dao, Van Tang Nguyen, "Students' Difficulties in the Practice of Volleyball in School Physical Education: An Analysis Based on Tactical Principles," International Journal of Human Movement and Sports Sciences, Vol. 9, No. 1, pp. 41-47, 2021. DOI: 10.13189/saj.2021.090106

[24] Polevoy G. G., "Use of Exercise Classics in Physical Education Classes for the Development of Vestibular Stability of Schoolchildren," International Journal of Human Movement and Sports Sciences, Vol. 9, No. 2, pp. 180-184, 2021. DOI: 10.13189/saj.2021.090203. 